\title{
NUTRIENT RETURN THROUGH LITTERFALL IN A Eucalyptus dunnii Maiden STAND IN SANDY SOIL ${ }^{1}$
}

Aline Aparecida Ludvichak ${ }^{2 *}$, Mauro Valdir Schumacher ${ }^{3}$, Grasiele Dick ${ }^{4}$, Dione Richer Momolli ${ }^{5}$, Huan Pablo de Souza ${ }^{6}$ and Claudiney do Couto Guimarães ${ }^{7}$

\footnotetext{
${ }^{1}$ Received on 27.08.2015 accepted for publication on 04.10.2016.

${ }^{2}$ Universidade Federal de Santa Maria, Mestrado em Engenharia Florestal, Santa Maria, RS - Brasil. E-mail:<aline_lud@yahoo.com.br>.

${ }^{3}$ Universidade Federal de Santa Maria, Departamento de Ciências Florestais, Santa Maria, RS - Brasil. E-mail: $<$ mvschumacher@gmail.com>.

${ }^{4}$ Universidade Federal de Santa Maria, Programa de Pós-Graduação em Engenharia Florestal, Santa Maria, RS - Brasil. Email:<grasidick@hotmail.com>.

${ }^{5}$ Universidade Federal de Santa Maria, Graduando em Engenharia Florestal, Santa Maria, RS - Brasil.

${ }^{6}$ Universidade Federal de Santa Maria, Programa de Pós-Graduação em Engenharia Florestal, Santa Maria, RS - Brasil. Email:< huan.pablo@hotmail.com>.

${ }^{7}$ Stora Enso Florestal, Rosário do Sul, RS - Brasil. E-mail:<claudiney.guimaraes@storaenso.com>.

*Corresponding author.
}

\begin{abstract}
In a forest stand, litterfall is primarily responsible for the retention and return of nutrients to the soil. The objective of this study was to evaluate the return of nutrients through litterfall in a stand of Eucalyptus dunnii in a Pampa biome. For quantification of litterfall, four $420-\mathrm{m}^{2}$ installments were marked; within each one, four $0.50-\mathrm{m}^{2}$ collection plots were distributed. For the collection of thick branches, four $7.00-\mathrm{m}^{2} \mathrm{sub}-$ plots were staked out. The collected litterfall was separated into leaf, twig, thick branch, and miscellany fractions for subsequent chemical analysis. The total litterfall measured was $6.99 \mathrm{Mg} \mathrm{ha}^{-1} \mathrm{yr}^{-1}$, and comprised $61.57 \%$ leaves, $17.34 \%$ twigs, $13.83 \%$ thick branches, and $7.26 \%$ miscellany. The total amount of macronutrients in the litterfall was $160.22 \mathrm{~kg} \mathrm{ha}^{-1} \mathrm{yr}^{-1}$, and the macronutrient transfer order was the same for the leaf, twig, and thick branch fractions $(\mathrm{Ca}>\mathrm{N}>\mathrm{K}>\mathrm{Mg}>\mathrm{S}>\mathrm{P})$. The total quantity of micronutrients was $7.55 \mathrm{~kg} \mathrm{ha}^{-1} \mathrm{yr}^{-1}$, and the transfer order was $\mathrm{Mn}>\mathrm{Fe}>\mathrm{B}>\mathrm{Zn}>\mathrm{Cu}$. Maintaining litterfall on the site, especially in degraded or low fertility soils like in the Pampa biome, may contribute to possible improvements in soil characteristics.
\end{abstract}

Keywords: Forest nutrition; Nutrient cycling; Pampa biome.

\section{DEVOLUÇÃO DE NUTRIENTES ATRAVÉS DA SERAPILHEIRA PRODUZIDA EM UM POVOAMENTO DE Eucalyptus dunnii Maiden EM SOLO ARENOSO}

\begin{abstract}
RESUMO - A produção de serapilheira é a principal responsável pela retenção e devolução de nutrientes para o solo em um povoamento florestal. O objetivo deste trabalho foi avaliar a devolução de nutrientes por meio da serapilheira produzida em um povoamento de Eucalyptus dunnii, no bioma Pampa. Para a quantificação da serapilheira produzida, foram demarcadas quatro parcelas de $420 \mathrm{~m}^{2}$, e no interior de cada parcela foram distribuidos quatro coletores de $0,50 \mathrm{~m}^{2}$. Para a coleta dos galhos grossos demarcou-se quatro sub-parcelas de 7,00 $\mathrm{m}^{2}$. O material coletado foi separado nas frações folhas, galhos grossos, galhos finos e miscelanea, com posterior análise química. A serapilheira produzida foi de $6,99 \mathrm{Mg} \mathrm{ha}^{-1}$ ano-1, distribuída em $61,57 \%$, $17,34 \%, 13,83 \%$ e 7,26\%, nas folhas, galhos finos, galhos grossos e miscelânea, respectivamente. A quantidade de macronutrientes na serapilheira foi de $160,22 \mathrm{~kg} \mathrm{ha}^{-1}$ ano ${ }^{-1}$, sendo que, a ordem de transferência foi a mesma para as frações folhas, galhos finos e galhos grossos $(\mathrm{Ca}>N>K>M g>S>P$ ). Para os micronutrientes

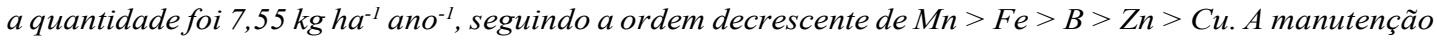
da serapilheira no sitio, principalmente em solos degradados ou de baixa fertilidade natural, como é o caso da região do bioma Pampa, poderá contribuir com possiveis melhorias nas características do solo.
\end{abstract}

Palavras-chave: Nutrição florestal; Ciclagem de nutrientes; Bioma Pampa. 


\section{INTRODUCTION}

Litterfall is primarily responsible for the retention and return of nutrients to the soil in an ecosystem, constituting a component of paramount importance in forests and forest plantations (FIGUEIREDOFILHO etal., 2003; VITAL, 2004; SCHUMACHER et al., 2013). According to Zimmermann et al. (2002) and Schumacher et al. (2004), litter production and the return of nutrients in forest stands are the most important means of biogeochemical cycling (nutrient flow in the soil-plant-soil system), especially in highly weathered soils of low fertility, where plant biomass is the main nutrient reservoir.

New eucalyptus plantations are being established in areas that lack prior significant forestry histories, such as the Pampa biome, which naturally has low fertility soils (CORRÊA et al., 2013; VIERA et al., 2014). Moraes (2012) stated that there are many questions about the potential environmental impacts that forestry can have on the region, especially when modifying the local biome.

The Pampa biome is the only Brazilian biome restricted to one state. This biome occupies $63 \%$ of the Rio Grande do Sul state, with an area of approximately 176,500 square kilometers that extends into Uruguay and Argentina (IBGE, 2004). The Pampa has diverse vegetation consisting mainly of grasses, herbs, and a few scattered shrubs; however, it is estimated that approximately $49 \%$ of its area has lost its native vegetation due to anthropogenic exploitation for livestock grazing, (the main economic activity of the region), rice growing, or eucalyptus plantations (BRASIL, 2007).

Each ecosystem has its own characteristic storage and nutrient cycling patterns among its components. Thus, studies on nutrient cycling are critical to determining the sustainability of eucalyptus plantations. In addition, a better understanding of nutrient dynamics in culture allows for the optimization of nutritional management factors such as dosage, methodology, and timing of fertilizer application in certain ecosystems (ZAIA; GAMA-RODRIGUES, 2004; GODINHO et al., 2014.). Despite the importance of the forestry sector to the Rio Grande do Sul economy, some aspects, especially those related to the interactions of these crops with the environment, have not been widely studied (MORAES, 2012).

The objective of this study was to evaluate the return of nutrients through litterfall in a stand of Eucalyptus dunnii Maiden in soil subject to arenization in the Pampa biome.

\section{MATERIALS AND METHODS}

\subsection{Characterization of the site}

The study was conducted at Fazenda Sesmaria Santo Inácio $\left(29^{\circ} 47^{\prime} \mathrm{S}, 55^{\circ} 17^{\prime} \mathrm{W}\right)$, owned by Stora Enso Florestal RS Ltda. The site is located in the city of Alegrete, by the western border of the Rio Grande do Sul state, Campanha region. According to the climate classification proposed by Matzenauer et al. (2011), the region has a humid subtemperate climate, with an average annual temperature and rainfall of $18.6^{\circ} \mathrm{C}$ and $1,574 \mathrm{~mm}$, respectively. The region may have a dry period in summer.

The study area has dystrophic typic Paleudult soil (EMBRAPA, 2006). Chemical properties of the soil were analyzed according to the methodology described by Tedesco et al. (1995) at the time of settlement implementation (Table 1). According to the interpretation suggested by CQFS (2004), the analysis showed that the soil had low organic matter content, very low $\mathrm{pH}$, very low $\mathrm{Ca}$, low $\mathrm{Mg}$, very low base saturation (V\%), and high aluminum saturation $(\mathrm{m} \%)$, representing a low fertility soil.

Table 1 - Chemical and physical characteristics of the soil in a Eucalyptus dunnii stand in Alegrete, RS.

Tabela 1 - Características químicas e físicas do solo no povoamento de Eucalyptus dunnii em Alegrete, RS.

\begin{tabular}{|c|c|c|c|c|c|c|c|c|c|c|c|c|c|c|}
\hline \multirow{2}{*}{$\begin{array}{c}\text { Depth. } \\
\mathrm{cm}\end{array}$} & \multirow{2}{*}{$\begin{array}{c}\mathrm{Ds}^{\mathrm{a}} \\
\mathrm{g} \mathrm{cm}^{-3}\end{array}$} & \multirow{2}{*}{$\begin{array}{c}\mathrm{pH} \\
\mathrm{H}_{2} \mathrm{O}\end{array}$} & \multirow{2}{*}{$\begin{array}{c}\mathrm{OM}^{\mathrm{b}} \\
\%\end{array}$} & $\mathrm{P} *$ & $\mathrm{~K}^{*}$ & $\mathrm{Ca}$ & $\mathrm{Mg}$ & Al & $\mathrm{m}^{\mathrm{c}}$ & $\mathrm{v}^{\mathrm{d}}$ & $\mathrm{S}$ & B & $\mathrm{Cu}$ & $\mathrm{Zn}$ \\
\hline & & & & \multicolumn{2}{|c|}{$\overline{--\mathrm{mg} \mathrm{dm}^{-3}--}$} & \multicolumn{3}{|c|}{----- $\mathrm{cmol}_{\mathrm{c}} \mathrm{dm}^{-3}-----$} & \multicolumn{2}{|c|}{----- \% ----- } & \multicolumn{4}{|c|}{------- $\mathrm{mg} \mathrm{dm}^{-3}-------$} \\
\hline $0-20$ & 1.52 & 4.74 & 1.00 & 1.87 & 20.3 & & & 1.9 & & & & & 2.29 & 0.5 \\
\hline 20 & 1.58 & & & & 12 & & & & & & & & & 0. \\
\hline & & & & & 9 & & & & & & & & 2.20 & 0.2 \\
\hline & & & & & 8. & & & 2.0 & & & & & 2.23 & 0.2 \\
\hline $30-100$ & 1.43 & 5.00 & 0.72 & 1.54 & 8.3 & 1.88 & 0.40 & 1.75 & 43.1 & 21.22 & 6.12 & 0.43 & 2.01 & 0.29 \\
\hline
\end{tabular}

* Extraction method Melich I; ${ }^{\mathrm{a} S o i l}$ density; ${ }^{\mathrm{b}}$ Organic matter; ${ }^{\mathrm{c}}$ Aluminum saturation; ${ }^{\mathrm{d}}$ Base saturation.

Revista Árvore, Viçosa-MG, v.40, n.6, p.1041-1048, 2016 
In 2008 E. dunnii seeds were planted in a compartment that had been degraded by agriculture and grazing and had rarely exhibited arenization points. Plant spacing was $2.0 \mathrm{~m} \times 3.5 \mathrm{~m}$.

The area was prepared with ant control solution, herbicide application, in line subsoiling (using $300 \mathrm{~kg}$ $\mathrm{ha}^{-1} \mathrm{~N}-\mathrm{P}_{2} \mathrm{O}_{5}-\mathrm{K}_{2} \mathrm{O} 06-30-06+0.6 \%$ boron), irrigation, and hoeing. After 90 days of cultivation, $140 \mathrm{~kg} \mathrm{ha}^{-1} \mathrm{~N}$ $\mathrm{P}_{2} \mathrm{O}_{5}-\mathrm{K}_{2} \mathrm{O} 20-05-22+0.2 \%+0.4 \%$ boron zinc was incorporated into the soil near the seedlings. At 270 days, $140 \mathrm{~kg} \mathrm{ha}^{-1} \mathrm{~N}-\mathrm{P}_{2} \mathrm{O}_{5}-\mathrm{K}_{2} \mathrm{O} 22-00-18+1.0 \%$ sulfur $+0.3 \%$ boron was applied mechanically between lines.

At the beginning of the study, when the subjects were 60 months old, the stand had an average DBH (diameter at breast height, $1.30 \mathrm{~m}$ from ground level) of $11.9 \mathrm{~cm}$, an average height of $13.8 \mathrm{~m}$ with 1,143 individuals per hectare, and a total trunk volume (with bark) of $124.3 \mathrm{~m}^{3} \mathrm{ha}^{-1}$.

\subsection{Litterfall}

For quantification of litterfall, four $20.0 \mathrm{~m} \times 21.0$ $\mathrm{m}\left(420 \mathrm{~m}^{2}\right)$ plots were marked in the settlement area. Within each plot, for sampling fractions leaves, thin branches (diameter less than $0.5 \mathrm{~cm}$ ) and miscellany, were distributed four collectors of $0.50 \mathrm{~m}^{2}$ systematically (on the line between two trees, between the lines between two trees, diagonally between four trees, and close to the tree bole). For the thick branch (diameter 0.5 $\mathrm{cm}$ ) fraction, four $7.00 \mathrm{~m}^{2}$ subplots were demarcated in four different positions: two with an average $\mathrm{DBH}$ tree at the center, one with a mean $\mathrm{DBH}$ tree plus one standard deviation at the center, and one with a medium $\mathrm{DBH}$ tree minus one standard deviation at the center.

Material was collected every two weeks from January to December 2013 and was forwarded to the laboratory, where it was separated into leaf, twig, thick branch, miscellany fractions, and was combined into monthly composite samples. The samples were placed in packaging paper, dried in an air-circulating oven at $70^{\circ} \mathrm{C}$ for 72 hours, and weighed to determine the dry mass. After weighing, samples were ground using a Wiley mill with a 30 size mesh screen for subsequent chemical analysis.

Nutrient concentrations for each fraction were determined by chemical analysis following the methodology described by Tedesco et al. (1995) and Miyazawa et al. (2009). Nitrogen was determined with the Kjeldahl (sulfuric digestion) method; phosphorus and boron were determined by visible spectrophotometry (after nitric-perchloric digestion and dried digestion, respectively), potassium by flame photometry, sulfur by turbidimetry, and calcium, magnesium, copper, iron, manganese and zinc by atomic absorption spectrophotometry (after nitric-perchloric digestion).

Litterfall per hectare was estimated as a function of the area and the average monthly dry mass of the sample units. The total amounts of nutrients contained in each fraction were estimated by multiplying the concentrations of nutrients by dry weight.

\subsection{Statistical analysis}

Statistical analysis was performed using Assistat 7.7® (SILVA; AZEVEDO, 2002). Analysis of variance was performed on the data, assuming a completely randomized design with four treatments (the litter fractions) and twelve repetitions (months), and a Tukey test was performed to compare means $(\alpha=0.05)$.

\section{RESULTS}

Total litterfall was $6.99 \mathrm{Mg} \mathrm{ha}^{-1}$ year $^{-1}$. The leaf fraction constituted the largest fraction of litterfall $(61.57 \%)$, followed by the twig (17.34\%), thick branch $(13.83 \%)$ and miscellany fractions (7.26\%). Table 2 presents the monthly mean and total depositions for each fraction of litter during 2013.

Table 2 - Litterfall in a Eucalyptus dunnii stand, Alegrete, RS, in 2013.

Tabela 2 - Produção de serapilheira em um povoamento de Eucalyptus dunnii, em Alegrete, RS, no ano de 2013.

\begin{tabular}{lccc}
\hline Fraction & $\mathrm{kg} \mathrm{ha}^{-1} \pm$ deviation & $(\%)^{*}$ & Mean monthly \\
\hline Leaves & $4306.74 \pm 233.81$ & 61.57 & 358.89 \\
Twigs & $1213.04 \pm 84.38$ & 17.34 & 101.09 \\
Thick branches & $967.74 \pm 72.45$ & 13.83 & 80.65 \\
Miscellany & $507.51 \pm 35.52$ & 7.26 & 42.29 \\
Total & $6995.03 \pm 338.08$ & 100.00 & 582.92 \\
\hline
\end{tabular}

* Correspond to the percentage of each fraction in the total litterfall. 
The leaf fraction exhibited the highest nutrient concentrations for all macronutrients (Table 3 ). In almost all of the studied fractions, Ca was the highest concentration nutrient, with the exception being the miscellany fraction, in which $\mathrm{N}$ was the highest concentration nutrient. Among the macronutrients, $\mathrm{P}$ and $\mathrm{S}$ had the lowest concentrations, possibly since $\mathrm{P}$ is a highly mobile nutrient in the phloem of plants and therefore can be translocated to young plant tissues during senescence. Among the tested micronutrients, Mn exhibited the highest concentration in all litter fractions (Table 3 ).

The total nutrient return to the soil was 160.22 $\mathrm{kg} \mathrm{ha}^{-1} \mathrm{yr}^{-1}$, with $46.23 \%$ of the total from Ca (Table 4). Macronutrient transfer orders were the same for the leaf, twig, and branch fractions $(\mathrm{Ca}>\mathrm{N}>\mathrm{K}>\mathrm{Mg}>$
$\mathrm{S}>\mathrm{P}$ ). The miscellany fraction exhibited a transfer order of $\mathrm{N}>\mathrm{Ca}>\mathrm{K}>\mathrm{Mg}>\mathrm{S}>\mathrm{P}$. For soil micronutrients, the nutrient return was $7.55 \mathrm{~kg} \mathrm{ha}^{-1}$ (Table 5), $87.30 \%$ of which was $\mathrm{Mn}$. Micronutrient transfer orders for all fractions were $\mathrm{Mn}>\mathrm{Fe}>\mathrm{B}>\mathrm{Zn}>\mathrm{Cu}$.

The amount of nutrients present in the different litter fractions are presented in Table 4 and Table 5. We found that $74,11 \%$ of the total nutrients were found in the leaf fraction, resulting in the following nutrient content order: leaves $>$ twigs $>$ thick branches $>$ miscellany.

\section{DISCUSSION}

The overall litterfall quantity obtained in this study was similar to that found by other authors; Vieira et al. (2009) observed an average annual litter production

Table 3 - Average concentration of nutrients in fractions of litterfall in Eucalyptus dunnii stand in Alegrete, RS, in 2013. Tabela 3 - Concentração média de nutrientes nas frações da serapilheira produzida em povoamento de Eucalyptus dunnii

\begin{tabular}{|c|c|c|c|c|c|c|c|c|c|c|c|}
\hline \multirow[t]{2}{*}{ Fraction } & $\mathrm{N}$ & $\mathrm{P}$ & $\mathrm{K}$ & $\mathrm{Ca}$ & $\mathrm{Mg}$ & $\mathrm{S}$ & B & $\mathrm{Cu}$ & $\mathrm{Fe}$ & $\mathrm{Mn}$ & $\mathrm{Zn}$ \\
\hline & \multicolumn{6}{|c|}{------------------------------- $\mathrm{g} \mathrm{kg}^{-1}$---------------------------- } & \multicolumn{5}{|c|}{---------------------------- $\mathrm{mg} \mathrm{kg}^{-1}$----------------------------- } \\
\hline Leaves & $7.76 \mathrm{a}$ & $0.52 \mathrm{a}$ & $3.77 \mathrm{a}$ & $12.52 \mathrm{a}$ & $2.43 \mathrm{a}$ & $0.78 \mathrm{a}$ & $40.99 \mathrm{a}$ & $5.46 \mathrm{a}$ & $106.92 \mathrm{a}$ & $1252.73 \mathrm{a}$ & $12.44 \mathrm{a}$ \\
\hline Twigs & $2.97 \mathrm{c}$ & $0.17 \mathrm{~b}$ & $2.20 \mathrm{~b}$ & $7.59 \mathrm{bc}$ & $2.12 \mathrm{a}$ & $0.29 \mathrm{~b}$ & $10.07 \mathrm{bc}$ & $7.14 \mathrm{a}$ & $49.83 \mathrm{~b}$ & $504.89 \mathrm{~b}$ & $13.20 \mathrm{a}$ \\
\hline Thick branches & $1.81 \mathrm{c}$ & $0.17 \mathrm{~b}$ & $1.77 \mathrm{~b}$ & $9.21 \mathrm{ab}$ & $1.80 \mathrm{a}$ & $0.28 \mathrm{~b}$ & $6.66 \mathrm{c}$ & $5.89 \mathrm{a}$ & $51.18 \mathrm{~b}$ & $471.68 \mathrm{~b}$ & $24.60 \mathrm{a}$ \\
\hline Miscellany & $5.56 \mathrm{~b}$ & $0.32 \mathrm{~b}$ & $2.09 \mathrm{~b}$ & $4.61 \mathrm{c}$ & $2.00 \mathrm{a}$ & $0.37 \mathrm{~b}$ & $13.87 \mathrm{~b}$ & $4.80 \mathrm{a}$ & $108.37 \mathrm{a}$ & $480.92 \mathrm{~b}$ & $10.64 \mathrm{a}$ \\
\hline
\end{tabular}

*The values in the vertical followed by the same letter do not differ significantly by Tukey test at $5 \%$ error.

Table 4 - Amount of macronutrients in litterfall fractions from a Eucalyptus dunnii stand in Alegrete, RS, in 2013.

Tabela 4 - Quantidade de macronutrientes nas frações da serapilheira produzida em povoamento de Eucalyptus dunnii em Alegrete, $R S$, no ano de 2013.

\begin{tabular}{|c|c|c|c|c|c|c|}
\hline \multirow[t]{2}{*}{ Fraction } & $\mathrm{N}$ & $\mathrm{P}$ & $\mathrm{K}$ & $\mathrm{Ca}$ & $\mathrm{Mg}$ & $\mathrm{S}$ \\
\hline & \multicolumn{6}{|c|}{ - } \\
\hline Leaves & $33.76(79.98)^{*}$ & $2.29(82.97)$ & $17.13(73.24)$ & $51.55(71.74)$ & $10.36(65.20)$ & $3.32(80.78)$ \\
\hline Twigs & $3.66(8.67)$ & $0.18(6.52)$ & $2.93(12.53)$ & $8.48(11.80)$ & $2.64(16.61)$ & $0.38(9.25)$ \\
\hline Thick branches & $1.86(4.41)$ & $0.11(3.99)$ & $2.16(9.23)$ & $9.41(13.09)$ & $1.71(10.76)$ & $0.21(5.11)$ \\
\hline Miscellany & $2.93(6.94)$ & $0.18(6.52)$ & $1.17(5.00)$ & $2.42(3.37)$ & $1.18(7.43)$ & $0.20(4.87)$ \\
\hline Total & $42.21(100.00)$ & $2.76(100.00)$ & $23.39(100.00)$ & $71.86(100.00)$ & $15.89(100.00)$ & $4.11(100.00)$ \\
\hline
\end{tabular}

* Values in parentheses refer to the percentage $(\%)$ of each fraction in the total of certain macronutrients contained in the litter in the year of study.

Table 5 - Amount of micronutrients in litterfall fractions from a Eucalyptus dunnii stand in Alegrete, RS, in 2013.

Tabela 5 - Quantidade de micronutrientes nas frações da serapilheira produzida em povoamento de Eucalyptus dunnii em Alegrete, $R S$, no ano de 2013.

\begin{tabular}{lccccc}
\hline Fraction & $\mathrm{B}$ & $\mathrm{Cu}$ & $\mathrm{Fe}$ & $\mathrm{Mn}$ & $\mathrm{Zn}$ \\
\cline { 2 - 6 } & $-174.66(86.71)^{*}$ & $23.48(57.44)$ & $451.80(72.57)$ & $5222.66(79.18)$ & $55.22(58.84)$ \\
Leaves & $12.14(6.03)$ & $8.17(19.99)$ & $56.25(9.04)$ & $593.86(9.00)$ & $17.62(18.77)$ \\
Twigs & $6.64(3.30)$ & $6.13(15.00)$ & $53.95(8.67)$ & $535.56(8.12)$ & $16.04(17.09)$ \\
Thick branches & $7.98(3.96)$ & $3.10(7.58)$ & $60.54(9.72)$ & $243.57(3.69)$ & $4.97(5.30)$ \\
Miscellany & $201.42(100.00)$ & $40.88(100.00)$ & $622.54(100.00)$ & $6.595 .65(100.00)$ & $93.85(100.00)$ \\
Total &
\end{tabular}

* Values in parentheses refer to the percentage $(\%)$ of each fraction in the total of certain micronutrients contained in the litter in the year of study. 
of $5.8 \mathrm{Mg} \mathrm{ha}^{-1}$ in an E. urophylla $\times$ E. grandis settlement; Inkotte et al. (2015) observed an average annual litter production of $8.5 \mathrm{Mg} \mathrm{ha}^{-1}$ in an E. dunnii settlement. Corrêa et al. (2013) observed a deposition of approximately 4.1 $\mathrm{Mg} \mathrm{ha}^{-1} \mathrm{yr}^{-1}$ in an E. dunnii settlement; however, the plants used in the study were younger than those in our study, which could explain the difference in litter quantity.

Several studies observed that the predominant litter fraction was the leaf fraction. Like in the present study, Figueiredo Filho et al. (2003), Toledo and Pereira (2004), Corrêa et al. (2013), Tang et al. (2013) and Cizungu et al. (2014) stated that 60 to $93 \%$ of the collected litter was leaf litter. One explanation for this predominance is that the trees are young and consequently have not deposited many branches.

Viera et al. (2010) found a higher concentration of nutrients in the leaves and attributed this to the increased metabolic activity of leaf tissues. They mention that mobile nutrients are concentrated in the newer structures of the plant, even after senescence. Viera et al. (2014) studied E. urophylla $\times$ E. globulus litter and observed that $\mathrm{Ca}+\mathrm{N}$ represented more than $70 \%$ of the total macronutrients returned to the soil.

The miscellany fraction exhibited a higher $\mathrm{N}$ concentration than Ca concentration. This has also been recorded by Viera and Schumacher (2010) and Viera et al. (2014); the authors attribute this to the presence of reproductive wastes (which have higher concentrations of $\mathrm{N}$ ) in the miscellany fraction.

Hernández et al. (2009) studied E. dunnii and found a macronutrient transfer order of $\mathrm{Ca}>\mathrm{N}>\mathrm{Mg}>\mathrm{K}$ $>$ P. Viera et al. (2014), who studied E. urophylla $\times$ E. globulus, and Ashagrie and Zech (2013), who studied E. globulus, found a transfer order of $\mathrm{Ca}>\mathrm{N}>\mathrm{K}>$ $\mathrm{Mg}>\mathrm{S}>$ P. Corrêa et al. (2013), who studied E. dunnii, and Silva et al. (2015), who studied E. camaldulensis, observed a transfer order of $\mathrm{Ca}>\mathrm{N}>\mathrm{K}>\mathrm{Mg}>\mathrm{P}>$ $\mathrm{S}$, results similar to those obtained in this study. It is possible that $\mathrm{Ca}$ was dominant because of its low mobility in phloem, which hinders its translocation during senescence.

However, Vieira et al. (2009), (studying E. urophylla $\times$ E. grandis), Cunha et al. (2005) (studying E. grandis), and Freitas et al. (2013) (studying E. grandis $\times E$. urophylla) observed that the most abundant macronutrient in the litter was $\mathrm{N}$, and the nutrient transfer order was $\mathrm{N}>\mathrm{Ca}>\mathrm{K}>\mathrm{Mg}>\mathrm{P}$, demonstrating that nutrient input varied for each element. These differences were probably related to the soil conditions and physiological characteristics of the species.

The transfer order of micronutrients found in the present study $(\mathrm{Mn}>\mathrm{Fe}>\mathrm{B}>\mathrm{Zn}>\mathrm{Cu})$ was identical to that found by Corrêa et al. (2016) with E. dunnii in sandy soils and similar to that obtained by Viera et al. (2014) with E. urophylla $\times$ E. globulus $(\mathrm{Mn}>$ $\mathrm{Fe}>\mathrm{Zn}>\mathrm{B}>\mathrm{Cu})$.

The results obtained in this study were similar to those reported by Gill et al. (1987), who analyzed the nutrients in E. tereticornis litter in highly alkaline soils in India, observing the transfer order $\mathrm{Ca}>\mathrm{N}>$ $\mathrm{Mg}>\mathrm{K}>\mathrm{S}>\mathrm{P}$ for macronutrients and $\mathrm{Mn}>\mathrm{Fe}>$ $\mathrm{Zn}>\mathrm{Cu}$ for micronutrients.

In a study of E. grandis, Cunha et al. (2005) observed that the order of nutrient amounts in litter fractions was leaves $>$ branches $>$ bark $>$ reproductive structures. Demonstrating that the leaf fraction has relevance in litter deposition. This order occurs because plants try to minimize evaporation and, consequently, the energy expenditure, for biomass production.

In a study of E. dunnii on a degraded site, Corrêa et al. (2013) said the area had potential for development of eucalyptus plantations, provided that nutrients be supplied to the site; the low fertility of these soils was counteracted by basic fertilization and coverage practices, evidenced by the concentration of litter nutrients and the amount of litter produced.

The formation and decomposition of litter on degraded soils reactivate nutrient cycling between plants and soil, allowing the formation of a new pedological horizon with more suitable conditions for vegetation restoration (ANDRADE et al., 2003). These authors also claim that in production systems, litter plays an important role in protecting the soil from erosion agents and provides organic matter and nutrients to soil organisms and plants, helping maintain and/or improve both soil and production plant quality.

In a Pampa biome study with different land uses (eucalyptus, pasture and native pasture), Moraes (2012) stated that the eucalyptus culture had high potential residue deposits on the soil surface compared to native pasture or field uses. Our results demonstrate that when the aim is to increase organic matter and nutrient cycling,

Revista Árvore, Viçosa-MG, v.40, n.6, p.1041-1048, 2016 
the large quantity and high nutrient content of eucalyptus litter can improve soil characteristics when it is maintained on a site. This is especially important for degraded or low fertility soils like those in the Pampa biome region.

\section{CONCLUSION}

The litterfall production of a stand of Eucalyptus dunnii Maiden in soil subject to arenization in the Pampa biome was similar to that obtained in other studies.

The annual transfer of nutrients to the soil appeared to follow the descending order of $\mathrm{Ca}>\mathrm{N}>\mathrm{K}>\mathrm{Mg}$ $>\mathrm{S}>\mathrm{P}$ for macronutrients and $\mathrm{Mn}>\mathrm{Fe}>\mathrm{B}>\mathrm{Zn}>$ $\mathrm{Cu}$ for micronutrients, representing an annual return of $160.22 \mathrm{~kg} \mathrm{ha}^{-1}$ for macronutrients and $7.55 \mathrm{~kg} \mathrm{ha}^{-1}$ for micronutrients.

The maintenance of litter on a site may contribute to possible improvements in soil characteristics, especially for degraded or low fertility soils like those in the Pampa biome.

\section{ACKNOWLEDGMENTS}

We thank StoraEnso for grant support and FAPERGS and CNPq for granting scholarships to the authors.

\section{REFERENCES}

ANDRADE, A.G.; TAVARES, S.R.L.; COUTINHO, H.L.C. Contribuição da serapilheira para recuperação de áreas degradadas e para a manutenção da sustentabilidade de sistemas agroecológicos. Informe Agropecuário, v.24, n.220, p.55-63, 2003.

ASHAGRIE, Y.; ZECH, W. Litter production and nutrient cycling in two plantations and a Podocarpus falcatus dominated natural forest ecosystems in south-eastern highlands of Ethiopia. African Journal of Agricultural Research, v.8, n.38, p.48104818, 2013.

BRASIL, Ministério do Meio Ambiente. Mapa de Cobertura Vegetal dos Biomas

Brasileiros. 2007. [acessado em: 08 de ago. de 2016]. Disponível em:http://www.mma.gov.br/ estruturas/sbf_chm_rbbio/_arquivos/ mapas_cobertura_vegetal.pdf.
CIZUNGU, L.; STAELENS, J.; HUYGENS, D.; WALANGULULU, J.; MUHINDO, D.; CLEEMPUT, O.V.; BOECKX, P. Litterfall and leaf litter decomposition in a central African tropical mountain forest and Eucalyptus plantation. Forest Ecology and Management, v.326, p.109-116, 2014.

COMISSÃO QUÍMICA E FERTILIDADE DO SOLO - CQFS. Sociedade Brasileira de Ciência do Solo. Manual de adubação e de calagem para os estados do Rio Grande do Sul e de Santa Catarina. 10.ed. Porto Alegre: 2004. 400p.

CORRÊA, R.S.; SCHUMACHER, M.V.; MOMOLLI, D.R. Deposição de serapilheira e micronutrientes ao longo das estações do ano em um plantio de eucalipto estabelecido sobre pastagem natural degradada no bioma Pampa. Scientia Forestalis, v.44, n.110, p.435-442, 2016.

CORRÊA, R.S.; SCHUMACHER, M.V.; MOMOLLI, D.R. Deposição de serapilheira e macronutrientes em povoamento de Eucalyptus dunnii Maiden sobre pastagem natural degradada no bioma Pampa. Scientia Forestalis, v.41, n.97, p.65-74, 2013.

CUNHA, G.M.; GAMA-RODRIGUES, A.C.; COSTA, G.A. Ciclagem de nutrientes em Eucalyptus grandis W. Hill ex Maiden no Norte Fluminense. Revista Árvore, v.29, n.3, p.353-363, 2005.

EMPRESA BRASILEIRA DE PESQUISA AGROPECUÁRIA - EMBRAPA. Sistema brasileiro de classificação de solos. 2.ed. Rio de Janeiro: Embrapa Solos, 2006. 306p.

FIGUEIREDO FILHO, A.; MORAES, G.F.; SCHAAF, L.B.; FIGUEIREDO, D.J. Avaliação estacional a deposição de serapilheira em uma Floresta Ombrófila Mista localizada no Sul do Paraná. Ciência Florestal, v.13, p.11-18, 2003.

FREITAS, E.C.S.; OLIVEIRA NETO, S.N.; FONSECA, D.M.; SANTOS, M.V.; LEITE, H.G.; MACHADO, V.D. Deposição de serapilheira e de nutrientes no solo em sistema agrossilvipastoril com eucalipto e acácia. Revista Árvore, v.37, n.3, p.409-417, 2013. 
GILL, H.S.; ABROL, I.P.; SAMRA, J.S. Nutrient recycling through litter production in young plantations of Acacia nilotica and Eucalyptus tereticornis in a highly alkaline soil. Forest Ecology Management, v.22, n.1-2, p.57-69, 1987.

GODINHO, T.O.; CALDEIRA, M.V.W.; ROCHA, J.H.T.; CALIMAN, J.P.; TRAZZI, P.A.

Quantificação de biomassa e de nutrientes na serapilheira acumulada em trecho de floresta estacional semidecidual submontana, ES.

Cerne, v.20, n.1, p.11-20, 2014.

HERNÁNDEZ, J.; DEL PINO, A.; SALVO, L.; ARRARTE, G. Nutrient export and harvest residue decomposition patterns of a Eucalyptus dunnii Maiden plantation in temperate climate of Uruguay. Forest Ecology Management, v.258, n.2, p.92-99, 2009.

INKOTTE, J.; MAFRA, Á.L.; RIOS, P.D.; BARETTA, D.; VIEIRA, H.C. Deposição de serapilheira em reflorestamentos de eucalipto e florestas nativas nas regiões Planalto e Oeste do Estado de Santa Catarina. Scientia

Forestalis, v.43, n.106, p.261-270, 2015.

INSTITUTO BRASILEIRO DE GEOGRAFIA E ESTATÍSTICA - IBGE. Mapa de Biomas e de Vegetação do Brasil. 2004. [acessado em: 08 de ago. 2016] Disponível em: http:// www.ibge.gov.br/home/presidencia/noticias/ 21052004biomashtml.shtm.

MATZENAUER, R.; RADIN, B.; ALMEIDA, I.R. (Ed.). Atlas Climático: Rio Grande do Sul. Porto Alegre: Secretaria da Agricultura Pecuária e Agronegócio; Fundação Estadual de Pesquisa Agropecuária - FEPAGRO, 2011.

MIYAZAWA, M.; PAVAN, M.A.; MURAOKA, T.; CARMO, C.A.F.S.; MELO, W.J. Análise química de tecido vegetal. In: SILVA, F.C. (Org.). Manual de análises químicas de solos, plantas e fertilizantes. $2^{\mathrm{a}} \mathrm{ed}$. Brasília: Embrapa Informação Tecnológica, 2009. p.191-234.

MORAES, J.R. Alterações nos atributos microbiológicos do solo e nos estoques de carbono decorrentes do cultivo de eucalipto no Bioma Pampa.
Pelotas. 2012. 126f. Dissertação (Mestrado em Ciências) - Universidade Federal de Pelotas, Pelotas, 2012.

SCHUMACHER, M.V.; BRUN, E.J.; HERNANDES, J.L.; KÖNIG, F.G. Produção de serapilheira em Floresta de Araucaria angustifolia (Bertol.) Kuntze no Município de Pinhal Grande-RS. Revista Árvore, v.28, n.1, p.29-37, 2004.

SCHUMACHER, M.V.; CORRÊA, R.S.; VIERA, M.; ARAÚJO, E.F. Produção e decomposição de serapilheira em um povoamento de Eucalyptus urophylla x Eucalyptus globulus Maidenii. Cerne, v.19, n.3, p.509-508, 2013.

SILVA, C.F.; CARMO, E.R.; MARTINS, M.A.; FREITAS, M.S.M.; PEREIRA, M.G.; SILVA, E.M.R. Deposition and nutritional quality of the litter of pure stands of Eucalyptus camaldulensis and Acacia mangium.

Bioscience Journal, v.31, n.4, p.1081-1091, 2015 .

SILVA, F.A.S.; AZEVEDO, C.A.V. Versão do programa computacional Assistat para o sistema operacional Windows. Revista Brasileira de Produtos Agroindustriais, v.4, n.1, p.71-78, 2002.

TANG, G.; LI, K.; ZHANG, C.; GAO, C.; LI, B. Accelerated nutrient cycling via leaf litter, and not root interaction, increases growth of Eucalyptus in mixed-species plantations with Leucaena. Forest Ecology Management, v.310, n.2, p.45-53, 2013.

TEDESCO, M.J.; GINELLO, C.; BISSANI, C.A.; BOHNEN, H.; VOLKWEISS, S.J. Análise de solo, plantas e outros materiais. 2.ed. Porto Alegre: UFRGS, 1995. 174p.

TOLEDO, L.O.; PEREIRA, M.G. Dinâmica da deposição de serapilheira em florestas secundárias do município de Pinheiral, RJ. Floresta e Ambiente, v. 11, n.1, p.39-46, 2004.

VIEIRA, J.A.G.; TEIXEIRA, M.B.; LOSS, A.; LIMA, E.; ZONTA, E. Produção de serapilheira e retorno de nutrientes ao solo pela espécie Eucalyptus urograndis. Revista Brasileira de Agroecologia, v.4, n.2, p.40-43, 2009.

Revista Árvore, Viçosa-MG, v.40, n.6, p.1041-1048, 2016 
VIERA, M.; SCHUMACHER M.V. Variação mensal da deposição de serapilheira em povoamento de Pinus taeda L. em área de campo nativo em

Cambará do Sul-RS. Revista Árvore, v.34, n.3, p.487-494, 2010.

VIERA, M.; CALDATO, S.L; ROSA, S.F.; KANIESKI, M.R.; ARALDI, D.B.; SANTOS, S.R.; SCHUMACHER, M.V. Nutrientes na serapilheira em um fragmento de floresta estacional decidual, Itaara, RS. Ciência Florestal, v.20, n.4, p.611$619,2010$.

VIERA, M.; SCHUMACHER, M.V.; ARAÚJO, E.F.; CORRÊA, R.S.; CALDEIRA, M.V.W. Deposição de serapilheira e nutrientes em plantio de Eucalyptus urophylla x E. globulus. Floresta Ambiente, v.21, n.3, p.327-338, 2014.
VITAL, A.R.T.; GUERRINI, I.A.; FRANKEN, W.K.; FONSECA, R.C.B. Produção de serapilheira e ciclagem de nutrientes de uma floresta Estacional Semidecidual em Zona Ripária. Revista Árvore, v.28, n.6, p.793-800, 2004.

ZAIA, F.C.; GAMA-RODRIGUES, A.C. Ciclagem e balanço de nutrientes em povoamentos de eucalipto na região Norte Fluminense. Revista Brasileira de Ciência do Solo, v. 28, n.5, p.843-852, 2004.

ZIMMERMANN, S.; BRAUN, S.; CONEDERA, H.; BLASER, P. Macronutrient inputs by litterfall as opposed to atmospheric deposition into two contrasting chestnut forest stands in southern Switzerland. Forest Ecology Management, v.161, n.1-3, p.289-302, 2002. 